\title{
Selection and validation of a set of reliable reference genes for quantitative sod gene expression analysis in $C$. elegans
}

\author{
David Hoogewijs ${ }^{1}$, Koen Houthoofd ${ }^{1}$, Filip Matthijssens ${ }^{1}$, Jo Vandesompele ${ }^{2}$ \\ and Jacques R Vanfleteren*1
}

Address: ${ }^{1}$ Department of Biology and Center for Molecular Phylogeny and Evolution, Ghent University, B-9000 Ghent, Belgium and ${ }^{2}$ Center for Medical Genetics Ghent, Ghent University Hospital, B-9000 Ghent, Belgium

Email: David Hoogewijs - David.Hoogewijs@UGent.be; Koen Houthoofd - Koen.Houthoofd@UGent.be; Filip Matthijssens - Filip.Matthijssens@UGent.be; Jo Vandesompele - Joke.Vandesompele@UGent.be; Jacques R Vanfleteren* - Jacques.Vanfleteren@UGent.be

* Corresponding author

Published: 22 January 2008

BMC Molecular Biology 2008, 9:9 doi:10.1 186/1471-2199-9-9
Received: 7 September 2007

Accepted: 22 January 2008

This article is available from: http://www.biomedcentral.com/I47I-2199/9/9

(c) 2008 Hoogewijs et al; licensee BioMed Central Ltd.

This is an Open Access article distributed under the terms of the Creative Commons Attribution License (http://creativecommons.org/licenses/by/2.0), which permits unrestricted use, distribution, and reproduction in any medium, provided the original work is properly cited.

\begin{abstract}
Background: In the nematode Caenorhabditis elegans the conserved Ins/IGF-I signaling pathway regulates many biological processes including life span, stress response, dauer diapause and metabolism. Detection of differentially expressed genes may contribute to a better understanding of the mechanism by which the Ins/IGF-I signaling pathway regulates these processes. Appropriate normalization is an essential prerequisite for obtaining accurate and reproducible quantification of gene expression levels. The aim of this study was to establish a reliable set of reference genes for gene expression analysis in $C$. elegans.

Results: Real-time quantitative PCR was used to evaluate the expression stability of 12 candidate reference genes (act-I, ama-I, cdc-42, csq-I, eif-3.C, mdh-I, gpd-2, pmp-3, tba-I, Y45FI OD.4, rgs-6 and unc-16) in wild-type, three Ins/IGF-I pathway mutants, dauers and L3 stage larvae. After geNorm analysis, cdc-42, pmp-3 and Y45FIOD.4 showed the most stable expression pattern and were used to normalize 5 sod expression levels. Significant differences in mRNA levels were observed for sod$I$ and sod-3 in daf-2 relative to wild-type animals, whereas in dauers sod- $I$, sod-3, sod-4 and sod-5 are differentially expressed relative to third stage larvae.

Conclusion: Our findings emphasize the importance of accurate normalization using stably expressed reference genes. The methodology used in this study is generally applicable to reliably quantify gene expression levels in the nematode $C$. elegans using quantitative PCR.
\end{abstract}

\section{Background}

Real-time quantitative PCR (qPCR) has become a very powerful tool for gene expression studies. One of the main difficulties associated with this highly sensitive technique is the necessity of accurate normalization, to account for varying amounts of cDNA input. This variation is inherent to the multistep process required to extract and process the RNA. The use of internal controls or reference genes has become the method of choice to account for this source of variation. The choice of an appropriate internal standard is therefore critical for relative gene expression analysis in order to obtain consistent and reliable results, especially when measuring small expression differences. A suitable reference gene to which 
expression can be normalized should have constant expression in all samples under investigation and should be insensitive to varying experimental treatments.

Although the nematode C. elegans is a commonly used model organism that has proven its importance in the unraveling of many important signaling pathways, to date no comprehensive analysis has been performed to validate candidate reference genes for gene expression analysis. Therefore, commonly used reference genes such as act1 and ama-1 are often used without validating their usefulness. However, several reports indicate that the expression of commonly used reference genes can vary under different experimental conditions [1-4], possibly leading to dramatic misinterpretation of the expression level of a target gene. Although there is no universally accepted approach for data normalization, the method of using multiple stably expressed reference genes is currently the golden standard [5]. The straightforward method developed by Vandesompele and colleagues [6] to identify the most stably expressed reference genes from a set of candidate control genes can be used to normalize gene expression levels (geNorm). Their method also allows the determination of the optimal number of genes required for reliable normalization of qPCR generated gene expression data. They advocate use of the geometric mean of multiple stably expressed reference genes for normalization of relative quantities. This approach has been widely implemented by many researchers and has been statistically validated by Szabo et al. [7] and by the bootstrap procedure of Gabrielsson et al. [8], but surprisingly seems to be neglected in the C. elegans research field.

The Ins/IGF-1 signaling (IIS) pathway is a well-known life span regulator in C. elegans, Drosophila and mice $[9,10]$. A reduced activity of the pathway in C. elegans leads to nuclear localization of the transcription factor DAF-16, causing dauer formation and extended adult life span. Long-lived IIS mutants are highly resistant to a wide diversity of stressors, including enhanced survival upon exposure to the superoxide generator paraquat [11]. Given the potential role of reactive oxygen species in the ageing process, it is assumed that enzymes involved in the breakdown of ROS play an important role in the longevity phenotype of dauers and long-lived IIS mutants. Five different genes encoding superoxide dismutase (SOD) have been predicted in C. elegans. sod-1 and sod-5 encode cytosolic CuZnSODs. sod-4 expresses two splice variants, one membrane bound and one secreted. sod-2 and sod-3 encode mitochondrial MnSODs. It is well-established that increased life span is often associated with increased stress resistance and high antioxidant activity. For example, the long life span of dauers and IIS mutants is associated with increased stress resistance and high SOD activity [12-15]. Northern blot and microarray analysis have shown that sod-3 and possibly also sod-5 are upregulated in dauers and daf-2 mutants [16-18].

We demonstrate the usefulness of geNorm to determine the expression levels of the sod genes in C. elegans. geNorm analysis evaluates the stability of candidate reference genes based on the mean pairwise variation of a gene with all other tested genes. We compared the expression level of the candidate reference genes in 6 different $C$. elegans samples to validate internal controls for the analysis of sod gene expression. The presented approach can be applied to accurately normalize the expression of any C. elegans gene of interest.

\section{Results}

We carefully selected 12 potential reference genes from different functional classes to minimize the chance of

Table I: Function of candidate reference genes. Amplification efficiency is determined using the formula $10^{-1 / s l o p e}$. For the actual calculations, the base of the exponential amplification function is used (e.g. 1.96 means $96 \%$ amplification efficiency).

\begin{tabular}{|c|c|c|c|c|}
\hline Gene symbol & Sequence name & Function & Primerconc. (nM) & Amplification efficiency \\
\hline act-I & T04CI2.6 & $\begin{array}{l}\text { Cytoskeletal structural } \\
\text { protein }\end{array}$ & 200 & 1.96 \\
\hline ama-l & F36A4.7 & RNA polymerase II & 400 & 1.85 \\
\hline cdc-42 & R07G3.I & RHO GTPase & 200 & 1.95 \\
\hline $\operatorname{csq}-1$ & F40EI0.3 & $\begin{array}{l}\text { Calcium ion binding } \\
\text { protein }\end{array}$ & 200 & 1.95 \\
\hline eif-3.C & T23D8.4 & Translation initiation factor & 300 & 1.92 \\
\hline mdh-I & $\mathrm{F} 2 \mathrm{OHII.3}$ & Malate dehydrogenase & 300 & 1.93 \\
\hline gpd-2 & KIOB3.8 & $\begin{array}{c}\text { Glyceraldehyde-3- } \\
\text { phosphate dehydrogenase }\end{array}$ & 300 & 1.94 \\
\hline pmp-3 & C54GI0.3 & Acyl-CoA transporter & 300 & 1.89 \\
\hline tba- $I$ & F26E4.8 & Alpha tubulin & 200 & 1.95 \\
\hline Y45FIOD.4 & Y45FI0D.4 & $\begin{array}{l}\text { Iron binding protein } \\
\text { involved in Fe-S cluster } \\
\text { formation }\end{array}$ & 200 & 2.07 \\
\hline
\end{tabular}


coregulation using two different approaches (Table 1). First we selected commonly used reference genes such as ama-1 (RNA polymerase II), act-1 (actin), eif-3.C (Translation initiation factor), gpd-2 (Glyceraldehyde-3-phosphate dehydrogenase) and tba-1 (tubulin). In a second approach we screened publicly available C. elegans microarray expression data $[19,20]$. In this procedure we ranked all genes according to their standard deviation in 553 experiments and chose potential reference genes within the top ranked ones based on the following three criteria: (1) functional description available, (2) expression data available for at least 500 experiments and (3) cDNA confirmed (to exclude erroneously predicted genes). This strategy resulted in $c d c-42, p m p-3, r g s-6, u n c-16$ and Y45F10D.4 as candidate reference genes. After initial screening, we found that two genes (rgs- 6 and unc-16) from the available expression data in Kim et al. [19] were expressed at very low levels and therefore excluded for further analysis.

In an attempt to validate the remaining 10 candidate reference genes as internal control for analysis of sod gene expression in C. elegans, we set up an experiment containing young adult wild-type (N2), three strains carrying mutations in the Ins/IGF pathway (daf-2, daf-16 and daf-2; daf-16), wild type dauer worms and wild-type L3 stage larvae. Data were collected using RNA from 3 replicate C. elegans cultures.

Since the reverse transcription step is the source of most of the variability in quantitative PCR [21], cDNA synthesis was performed in duplicate from each of the three different biological replicates and pooled to use as template in the PCR experiments. For every primer pair concentrations were optimized in a range between $200 \mathrm{nM}$ and 400 $\mathrm{nM}$, based on a standard curve made with dilution series of a mixture of all cDNA templates. These standard curves produced efficiencies between 1.85 and 2.07 (Table 1) with standard deviations ranging from 0.019 to 0.065 and correlation coefficients greater than 0.984 , as determined by qBase [22]. Three identical real-time qPCR experiments were performed. In each experiment, the expression levels of the candidate reference genes and sod genes were measured in duplicate in 6 different worm samples. The candidate control genes display a wide expression range with mean cycle threshold (Ct) values between 14.6 (act-1) and 28.1 (ama-1).

To identify the most stable reference genes we applied the geNorm program. The ranking of the candidate reference genes according to their stability measure value $(M)$ in every biological replicate is displayed in Table 2 . This gene expression stability measure $M$ is the mean pairwise variation between a candidate reference gene and all other tested candidates. A higher value of $\mathrm{M}$ means greater variation in expression. The stepwise elimination of genes with the highest $M$ values allows the ranking of the tested genes according to their expression stability. Interestingly, in the three biological repeat experiments $c d c-42$ and pmp3 turned out to be among the three best performing reference genes. Moreover, in each of the three biological repeats the ranking of the least stable genes included $m d h$ 1, act-1 and gpd-2. The consistent ranking of the best and worst reference genes illustrates the excellent correspondence and reproducibility between the 3 independently grown nematode cultures. Pairwise variations $V_{n / n+1}$ between each combination of sequential normalization factors (NF) were calculated by geNorm to determine the optimal number of reference genes required for accurate normalization. Based on the recommendations by Vandesompele et al. [6] we used a cut-off value of 0.15 , below which the inclusion of an additional reference gene does not result in a significant improvement of normalization (Figure 1). Following this criterion the inclusion of a third reference gene is required for assay set 1 , but not for analyzing replicate sets 2 and $3\left(\mathrm{~V}_{2 / 3}\right.$ values 0.130 and 0.065 , respectively). For consistency reasons we prefer to use the 3 most stably expressed genes for all 3 replicate assays (as also suggested as a general rule of thumb in Vandesompele et al. [6]).

Table 2: Ranking of candidate reference genes in order of their expression stability, decreasing from top to bottom. Average expression stability values (M) are shown between brackets. The 2 most stable genes cannot be ranked in order because of the required use of gene ratios for gene stability.

\begin{tabular}{|c|c|c|}
\hline Replicate I & Replicate 2 & Replicate 3 \\
\hline pmp-3/cdc-42 (0.1 I 7) & cdc-42/Y45FIOD.4 (0.323) & Y45FIOD.4/pmp-3 (0.092) \\
\hline $\operatorname{csq}-I(0.4 I 2)$ & pmp-3 (0.387) & cdc-42 (0.164) \\
\hline Y45FIOD.4 (0.502) & tba-I (0.429) & tba-I (0.293) \\
\hline tba-I (0.562) & $\operatorname{csq}-I(0.470)$ & $\operatorname{csq}-I(0.328)$ \\
\hline eif-3.C $(0.625)$ & eif-3.C (0.522) & ama-I (0.375) \\
\hline ama-I (0.67I) & gpd-2 (0.559) & eif-3.C (0.450) \\
\hline act-I (0.747) & ama-I (0.627) & act-I (0.502) \\
\hline gpd-2 (0.799) & act-I (0.688) & gpd-2 (0.55I) \\
\hline$m d h-l(0.889)$ & $m d h-I(0.770)$ & $m d h-l(0.601)$ \\
\hline
\end{tabular}




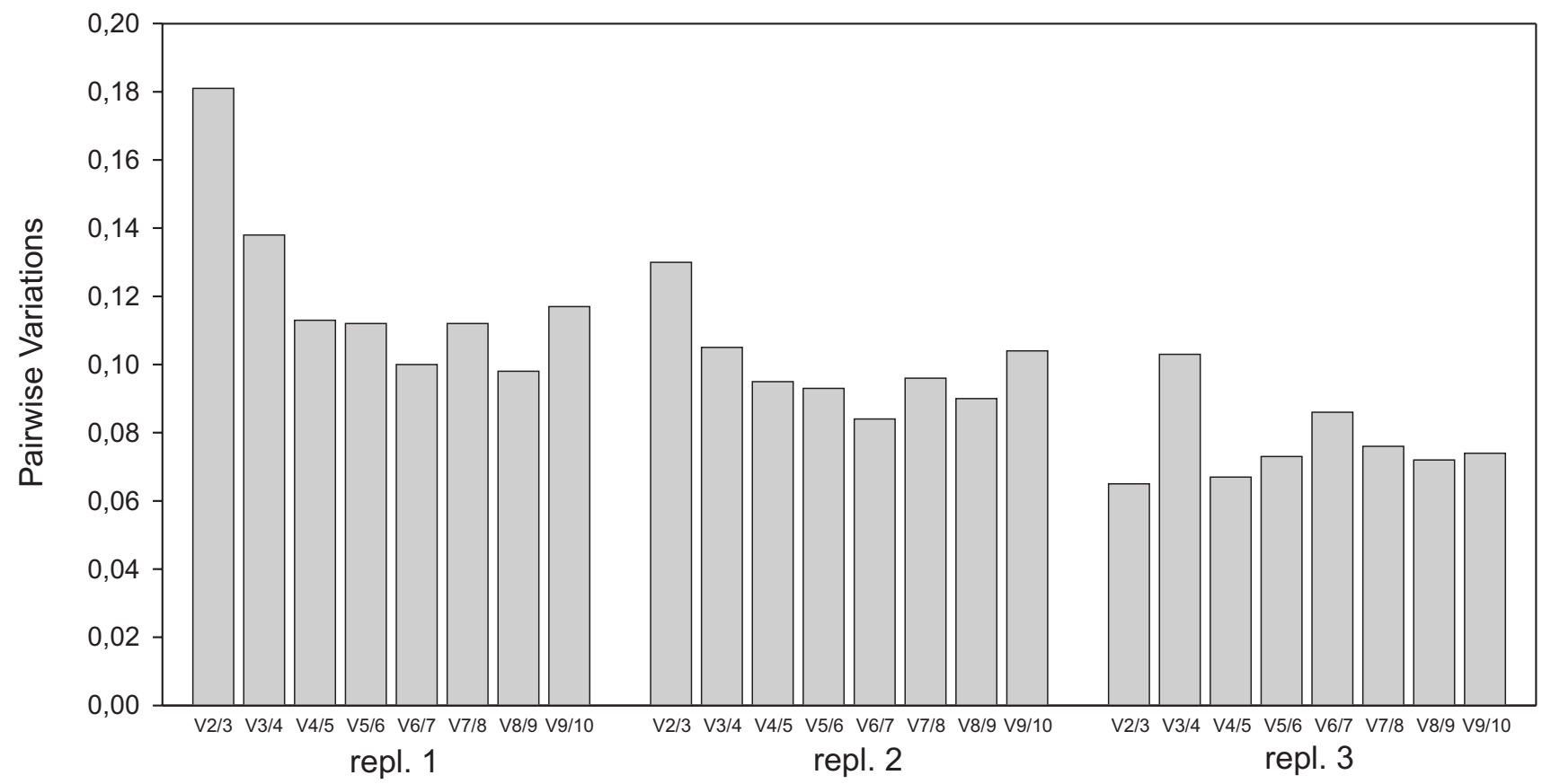

\section{Figure I}

Pairwise variations $\left(V_{n / n+1}\right)$ for all three biological replicate experiments. A large variation between two sequential normalisation factors means that the added gene has a significant effect and should preferably be included for calculation of the normalisation factor. Addition of a $4^{\text {th }}$ reference gene makes no further improvement of the normalisation factor in each of the three replicate assays.

To demonstrate the need for accurate relative quantification using suitable reference genes, the expression of the sod genes was studied. In each of the three assays a normalization factor based on the geometric mean of $c d c-42$, pmp-3 and Y45F10D.4 expression level was used to determine the relative expression level of all 5 sod genes. The average normalised sod mRNA values and the $95 \%$ confidence intervals are shown in Figure 2. The 95\% confidence intervals clearly illustrate that sod-1 and sod-3 are significantly upregulated in daf-2 relative to N2, in agreement with microarray studies of McElwee et al. [18] and Murphy et al. [17]. In dauers, sod-1 is significantly downregulated relative to L3, sod-3 is significantly upregulated relative to L3, and sod-4 and sod-5 are significantly upregulated relative to both $\mathrm{L} 3$ and $\mathrm{N} 2$.

We illustrate that normalization to a single reference gene without appropriate validation can lead to erroneous results by normalizing sod-1 to act-1, gpd-2 and $m d h-1$, respectively. When normalized only to act-1 the expression level of sod-1 in daf-2 differs by more than $40 \%$ and is not found to be significantly upregulated. Moreover the expression level of sod-1 in the dauer is upregulated instead of downregulated relative to L3. This shows that act-1 is unsuitable as a reference gene. When using $m d h-1$, only a modest, but not significant, increase by 2 -fold in daf-2 could be seen, and the expression level of sod-1 appears to be strongly upregulated in dauers. Moreover, if $g p d-2$ or $a m a-1$ had been used, no significant differential expression would have been detected in daf-2 mutants or dauers.

\section{Discussion}

An ideal reference gene is expressed at the same level in all cell types and under all experimental conditions. Numerous publications demonstrate that no single gene is able to fulfill these criteria. To reliably measure small expression differences, normalization using (ideally multiple) stably expressed reference genes is of crucial importance. This forced us to undertake a comprehensive analysis of different potential reference genes in 6 different $C$. elegans samples, including distinct developmental stages of the wild-type and adults of Ins/IGF pathway mutants.

We here provide validated assays for a newly developed set of multiple candidate reference genes.

The geNorm analysis revealed that $c d c-42$ and $p m p-3$ are among the 3 best performing reference genes identified in each of 3 biological replicates. They were picked up from 


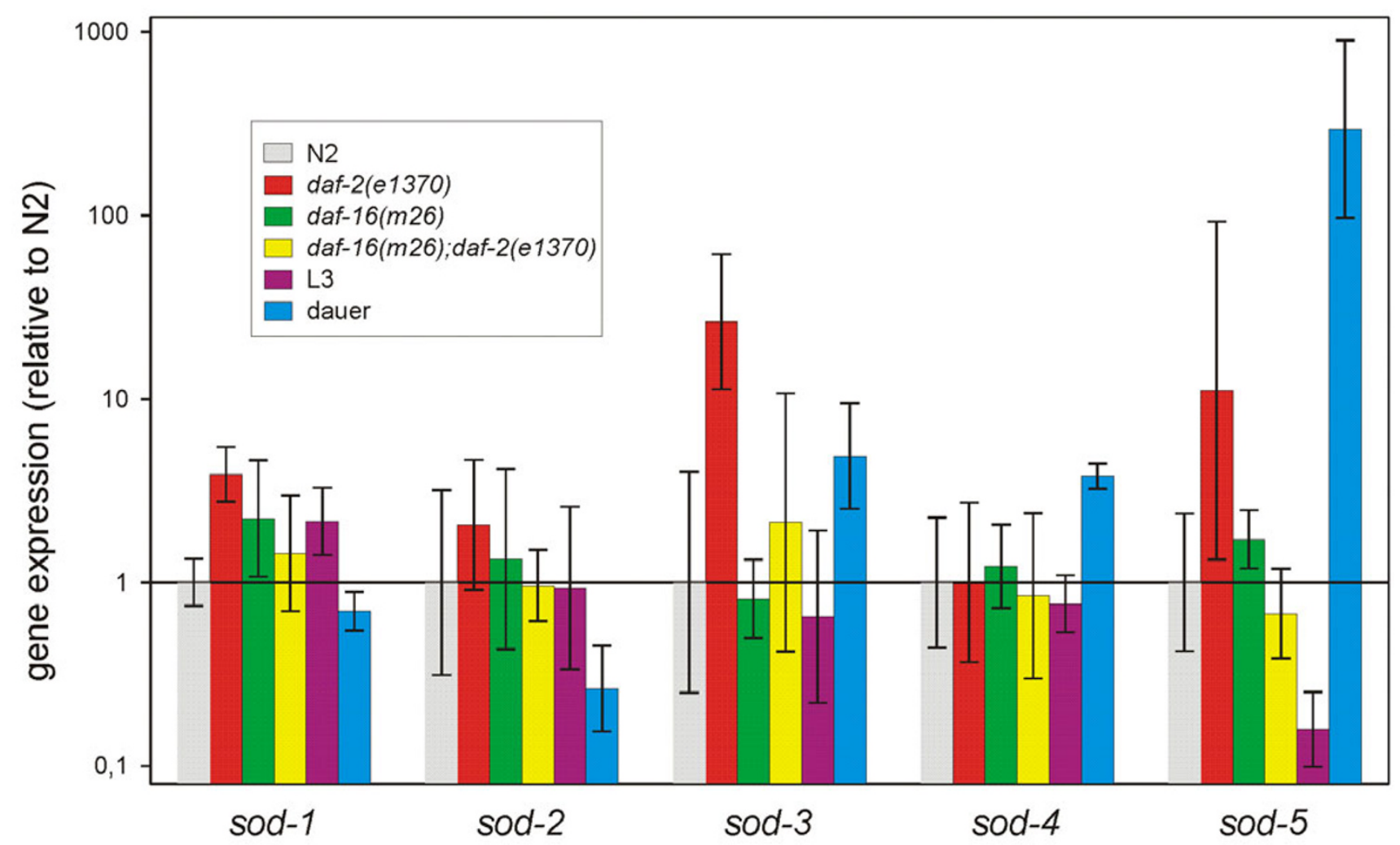

Figure 2

Normalized sod mRNA expression levels. The relative expression ratios are the average values from 3 replicate cultures. Bars indicate the $95 \%$ confidence interval of the mean (non-overlapping intervals denote significant differences at the 0.05 level). This statistic is a conservative criterion of statistical significance. All sod expression levels were normalized using the geometric mean of cdc-42, pmp-3 and Y45FI0D.4.

a microarray screen of differentially regulated genes (the Kim database) underscoring the reliability of this strategy to identify new candidate reference genes. They are far more stably expressed than conventional reference genes, at least in this study. Since in all 3 biological repeats addition of a fourth reference gene did not substantially improve the newly calculated normalization factor, there was no need to include more reference genes. Therefore we recommend to use three reference genes since we generally found that this number allows reliable and accurate quantification with a minimal effort.

Our analysis showed that $m d h-1$ is the least stable reference gene, which is in concordance with a previously published paper of McElwee et al. [23] who demonstrated by microarray analysis that $m d h-1$ was downregulated in dauers. Similarly, Mendenhall et al. [24] have recently shown that $g p d-2$ was upregulated in $d a f-2$ worms. Both studies suggest that $g p d-2$ and $m d h-1$ are downstream genes of DAF-16. As expected, geNorm ranked these genes as the two least stable reference genes in two of the three biolog- ical repeats. Interestingly, the most commonly used reference gene act-1 is one of the least stable reference genes as indicated by the geNorm analysis.

We used the reference genes to reveal the expression levels of sod-genes in long-lived Ins/IGF mutants and dauers. Our results largely confirm and extend previous studies using Norhern blots, SAGE and microarray analysis. The increased expression of sod-3 in dauers and daf-2 mutants has been well documented [16-18], [25-27]. Elevated expression of sod-4 in dauers was reported by Jones et al. [25]. We also detected an increased expression of sod-1 in daf-2 mutants which is in accordance with the increased activity of cytosolic SOD in long-lived Ins/IGF-1 pathway mutants [28] given that SOD-1 appears to be the most active CuZnSOD [29] (Matthijssens, unpublished data).

\section{Conclusion}

This study demonstrates the importance of appropriate validation of internal reference genes chosen for gene expression analysis using real-time qPCR. We show that 
candidate reference genes for accurate normalization of gene expression levels in C. elegans can be identified from publicly available microarray databases. The methodology used in the present study enables accurate analysis of differential gene expression of any set of candidate genes.

\section{Methods}

Nematode culturing

In this experiment, we compared the expression levels of candidate reference genes and five sod-genes in dauers compared to L3 larvae, and in adults of the wild-type N2 strain and the mutant strains daf-2(e1370ts), daf-16(m26) and daf-2(e1370ts); daf-16(m26). Reduction-of-function mutation in the gene daf-2, which encodes the Ins/IGF-1 receptor, causes extension of life span. This effect requires intact activity of the FOXO transcription factor DAF-16 and is therefore suppressed in strains that carry reductionor loss-of-function mutations in daf-16. Synchronous populations were initiated from eggs prepared by alkaline hypochlorite treatment of gravid adults. Worms were grown on cholesterol supplemented Nutrient Agar (OXOID) plates containing a lawn of freshly grown E. coli K12 cells [30]. Wild-type L3 worms were harvested after 30 hours of growth at $24^{\circ} \mathrm{C}$. At harvest, worms were rinsed off the plates, washed with S-buffer $(43.55 \mathrm{mM}$ $\mathrm{KH}_{2} \mathrm{PO}_{4}, 6.45 \mathrm{mM} \mathrm{K}_{2} \mathrm{HPO}_{4}$ and $100 \mathrm{mM} \mathrm{NaCl}$ in distilled water, $\mathrm{pH}$ 6), flash frozen and stored at $-75^{\circ} \mathrm{C}$ until use. Since daf-2 (e1370ts) is a constitutive dauer former at $24^{\circ} \mathrm{C}$, the cultures grown for harvesting adult worms of all strains were incubated at $17^{\circ} \mathrm{C}$ and shifted to $24^{\circ} \mathrm{C}$ after the animals had molted to the fourth larval stage. Samples were taken two days later. Dauers from N2 were obtained as described in Houthoofd et al. [14]. Briefly, agar plates ( $\mathrm{pH}$ 7.0) were seeded with freshly prepared eggs, hemoglobin and autoclaved E. coli cells and incubated at $24^{\circ} \mathrm{C}$. These conditions induce almost $100 \%$ dauer formation. Plates containing less than $99 \%$ dauers were discarded. Three independently grown replicates of all worm cultures were used to account for experimental variation.

\section{Isolation of RNA and cDNA synthesis}

Total RNA was isolated using the RNeasy Midi Kit (Qiagen) according to manufacturer's instructions. All samples were DNase treated (Zymo Research). A NanoDrop ND 1000 spectrophotometer was employed to analyze RNA concentration and purity. First strand cDNA was synthesized from $2 \mu \mathrm{g}$ RNA using an oligo(dT) primer and a Moloney murine leukemia virus reverse transcriptase (Fermentas) at $42^{\circ} \mathrm{C}$ for $1 \mathrm{~h}$.

\section{Real-time $R T-P C R$}

Full-length gene sequences were extracted from WormBase (Release WS170) and primers were designed by the Primer3 software [31] and tested for specifity using NCBI BLAST. The targets amplified by the primer pairs were evaluated with MFOLD software [32] in order to check for the formation of secondary structures at the site of primer binding. MFOLD analysis was performed using default settings and $50 \mathrm{mM} \mathrm{Na}^{+}, 3 \mathrm{mM} \mathrm{Mg}^{2+}$ and a temperature of $60^{\circ} \mathrm{C}$ (which is the annealing temperature of the primers). Primers were purchased from Invitrogen. Primer and amplicon information are listed in Table 3.

Quantitative RT-PCR was carried out using a Rotor-Gene 2000 centrifugal real-time cycler (Corbett Research) using the Platinum SYBR Green qPCR SuperMix-UDG (Invitrogen). Each reaction contained: $12.5 \mu \mathrm{l}$ of the Platinum SYBR Green qPCR SuperMix-UDG, $200 \mathrm{nM}, 300 \mathrm{nM}$ or $400 \mathrm{nM}$ of forward and reverse primers and $5 \mu \mathrm{lDNA}$ (1:40 RNA dilution), to a final volume of $25 \mu \mathrm{l}$. Amplification was performed in $0.1 \mathrm{ml}$ real-time PCR tubes (Corbett Research) placed in the 72-well rotor of the RotorGene instrument. The cycling conditions were as follows: $50^{\circ} \mathrm{C}$ for $2 \mathrm{~min}$, initial denaturation at $95^{\circ} \mathrm{C}$ for $2 \mathrm{~min}$, followed by 45 cycles of $15 \mathrm{~s}$ at $95^{\circ} \mathrm{C}, 30 \mathrm{~s}$ at $60^{\circ} \mathrm{C}$, and $30 \mathrm{~s}$ at $72^{\circ} \mathrm{C}$ (gain set at 8 for SYBR Green). Following the final cycle, melting curve analysis was performed to examine the specificity in each reaction tube (absence of primer dimers and other nonspecific products). The Rotor-Gene software allows automatic melting curve analysis for all

Table 3: Primer sequences for candidate normalization genes.

\begin{tabular}{|c|c|c|c|c|}
\hline Gene symbol & Sequence name & Forward primer & Reverse primer & Amplicon size \\
\hline act- $I$ & T04CI2.6 & gctggacgtgatcttactgattacc & gtagcagagcttctccttgatgtc & 114 \\
\hline ama-I & F36A4.7 & cctacgatgtatcgaggcaaa & cctccctccggtgtaataatg & 139 \\
\hline cdc-42 & R07G3.I & ctgctggacaggaagattacg & ctcggacattctcgaatgaag & III \\
\hline $\operatorname{csq}-1$ & F40EI0.3 & aactgaggttctgaccgagaag & tactggtcaagctctgagtcgtc & 111 \\
\hline eif-3.C & T23D8.4 & gctgagactgttaagggaatgg & gagcgaaacagtggcataaac & 99 \\
\hline mdh-I & $\mathrm{F} 2 \mathrm{OHII.3}$ & ctcgtgacgatctcttcaacac & gtcatagacaccagccttcttgag & 161 \\
\hline gpd-2 & $\mathrm{KIOB} 3.8$ & ctccatcgactacatggtctacttg & agctgggtctcttgagttgtagac & $15 \mid$ \\
\hline pmp-3 & C54GI0.3 & gttcccgtgttcatcactcat & acaccgtcgagaagctgtaga & 115 \\
\hline tba-I & F26E4.8 & gtacactccactgatctctgctgacaag & ctctgtacaagaggcaaacagccatg & 194 \\
\hline Y45FI0D.4 & Y45FIOD.4 & gtcgcttcaaatcagttcagc & gttcttgtcaagtgatccgaca & 139 \\
\hline
\end{tabular}


tested samples in a given run. SYBR Green fluorescence of the generated products was continuously monitored throughout the temperature ramp from 60 to $99^{\circ} \mathrm{C}$. The temperature rose in $1^{\circ}$ increments with a $5 \mathrm{~s}$ hold at each degree. A single melt peak for each reaction confirmed the identity of each PCR product. Each assay included a notemplate control for every primer pair. In addition, aliquots of each reaction mixture were analyzed by agarose gel electrophoresis to evaluate amplification of nonspecific products.

\section{Quantification and data analysis}

The threshold cycle $(\mathrm{Ct})$ values of the Rotor-Gene software version 6.0 (Corbett Research) were exported to qBase version 1.3.5, a free program for the management and automated analysis of qPCR data [22], for further analysis. All measurements were produced in duplicate, and for each primer set, reaction efficiency estimates were derived from standard curves that were generated using serial dilutions of a cDNA pool of all nematode samples. These were then used by qBase to transform the Ct values to relative quantities for analysis with geNorm 3.4 software [6]. The geNorm VBA applet for Microsoft Excel determines the most stable reference genes from a set of genes in a given panel of cDNA samples. After normalization using the geometric mean of the three most stable reference genes the normalized sod expression ratios were standardized to minimize inter-experimental variation. To this purpose, the normalized expression levels were converted into logarithmic values, divided by their standard deviation and multiplied by the mean standard deviation of the 3 experiments to calculate the mean standardized expression per nematode sample and its 95\% confidence interval. Finally, all values were linearized again using a power function, and plotted in a graph (Willems et al., manuscript in preparation). Differential gene expression was considered significant when the $95 \%$ confidence interval of the mean expression levels did not overlap (equivalent to $\mathrm{P}<0.05$ ).

\section{Authors' contributions}

$\mathrm{DH}$ and $\mathrm{KH}$ conceived and designed all experiments, analyzed data and wrote the manuscript; $\mathrm{DH}$ and FM performed experiments; JV provided expert input in data analysis and critically revised the manuscript; JRV supervised the study. All authors read and approved the final manuscript.

\section{Acknowledgements}

All strains used in this study were obtained from the Caenorhabditis Genetics Center. This work was supported by Ghent University (I2050 I0I), the F.W.O.-VI (G.0025.06) and the European Community (LSHM-CT-20045I 2020). KH and JV are postdoctoral fellows with the Fund for Scientific Research-Flanders (FWO).

\section{References}

I. Thellin O, Zorzi W, Lakaye B, De Borman B, Coumans B, Hennen G, Grisar T, Igout A, Heinen E: Housekeeping genes as internal standards: use and limits. J Biotechnol 1999, 75(2-3):291-295.

2. Hamalainen HK, Tubman JC, Vikman S, Kyrola T, Ylikoski E, Warrington JA, Lahesmaa R: Identification and validation of endogenous reference genes for expression profiling of $T$ helper cell differentiation by quantitative real-time RT-PCR. Anal Biochem 200I, 299(I):63-70.

3. Dheda K, Huggett JF, Bustin SA, Johnson MA, Rook G, Zumla A: Validation of housekeeping genes for normalizing RNA expression in real-time PCR. Biotechniques 2004, 37(I): I I 2-4, I I 6, I I 89.

4. Dheda K, Huggett JF, Chang JS, Kim LU, Bustin SA, Johnson MA, Rook $G A$, Zumla $A$ : The implications of using an inappropriate reference gene for real-time reverse transcription $P C R$ data normalization. Anal Biochem 2005, 344(I): I4I-I43.

5. Nolan T, Hands RE, Bustin SA: Quantification of mRNA using real-time RT-PCR. Nat Protoc 2006, I (3): I559-I 582.

6. Vandesompele J, De Preter K, Pattyn F, Poppe B, Van Roy N, De Paepe A, Speleman F: Accurate normalization of real-time quantitative RT-PCR data by geometric averaging of multiple internal control genes. Genome Biol 2002, 3(7):RESEARCH0034.

7. Szabo A, Perou CM, Karaca M, Perreard L, Quackenbush JF, Bernard PS: Statistical modeling for selecting housekeeper genes. Genome Biol 2004, 5(8):RESEARCH0059.

8. Gabrielsson BG, Olofsson LE, Sjogren A, Jernas M, Elander A, Lonn $M$, Rudemo M, Carlsson LM: Evaluation of reference genes for studies of gene expression in human adipose tissue. Obesity research 2005, I3(4):649-652.

9. Kenyon C: A conserved regulatory system for aging. Cell 200I, I05(2): | 65-168.

10. Partridge L, Gems D: Mechanisms of ageing: public or private? Nat Rev Genet 2002, 3(3): I65-I75.

II. Johnson TE, de Castro E, Hegi de Castro S, Cypser J, Henderson S, Tedesco P: Relationship between increased longevity and stress resistance as assessed through gerontogene mutations in Caenorhabditis elegans. Exp Gerontol 2001, 36(10): 1609-1617.

12. Anderson GL: Superoxide-dismutase activity in dauerlarvae of Caenorhabditis elegans (Nematoda, Rhabditidae). Can J Zool 1982, 60(3):288-29|.

13. Vanfleteren JR, De Vreese A: Rate of aerobic metabolism and superoxide production rate potential in the nematode Caenorhabditis elegans. J Exp Zool 1996, 274(2):93-100.

14. Houthoofd K, Braeckman BP, Lenaerts I, Brys K, De Vreese A, Van Eygen S, Vanfleteren JR: Ageing is reversed, and metabolism is reset to young levels in recovering dauer larvae of $\mathrm{C}$. elegans. Exp Gerontol 2002, 37(8-9): I015-1021.

15. Houthoofd K, Fidalgo MA, Hoogewijs D, Braeckman BP, Lenaerts I, Brys K, Matthijssens F, De Vreese A, Van Eygen S, Munoz MJ, Vanfleteren JR: Metabolism, physiology and stress defense in three aging Ins/IGF-I mutants of the nematode Caenorhabditis elegans. Aging Cell 2005, 4(2):87-95.

16. Honda $Y$, Honda $S$ : The daf-2 gene network for longevity regulates oxidative stress resistance and Mn-superoxide dismutase gene expression in Caenorhabditis elegans. Faseb J I999, I 3(I I): I 385-I393.

17. Murphy CT, McCarroll SA, Bargmann Cl, Fraser A, Kamath RS, Ahringer J, Li H, Kenyon C: Genes that act downstream of DAF16 to influence the lifespan of Caenorhabditis elegans. Nature 2003, 424(6946):277-283.

18. McElwee JJ, Schuster E, Blanc E, Thomas JH, Gems D: Shared transcriptional signature in Caenorhabditis elegans dauer larvae and long-lived daf-2 mutants implicates detoxification system in longevity assurance. J Biol Chem 2004, 279(43):44533-44543.

19. Kim SK, Lund J, Kiraly M, Duke K, Jiang M, Stuart JM, Eizinger A, Wylie BN, Davidson GS: A gene expression map for Caenorhabditis elegans. Science 2001, 293(5537):2087-2092.

20. Stuart Kim's C. elegans Microarray Database [http:// cmgm.stanford.edu/ kimlab/topomap/c. elegans topomap.htm]

21. Stahlberg A, Hakansson J, Xian X, Semb H, Kubista M: Properties of the reverse transcription reaction in $\mathrm{mRNA}$ quantification. Clin Chem 2004, 50(3):509-5 I5. 
22. Hellemans J, Mortier G, De Paepe A, Speleman F, Vandesompele J: qBase relative quantification framework and software for management and automated analysis of real-time quantitative PCR data. Genome Biol 2007, 8(2):RI9.

23. McElwee JJ, Schuster E, Blanc E, Thornton J, Gems D: Diapauseassociated metabolic traits reiterated in long-lived daf-2 mutants in the nematode Caenorhabditis elegans. Mech Ageing Dev 2006, I 27(5):458-472.

24. Mendenhall AR, LaRue B, Padilla PA: Glyceraldehyde-3-phosphate dehydrogenase mediates anoxia response and survival in Caenorhabditis elegans. Genetics 2006, 174(3): I I73-II87.

25. Jones SJ, Riddle DL, Pouzyrev AT, Velculescu VE, Hillier L, Eddy SR, Stricklin SL, Baillie DL, Waterston R, Marra MA: Changes in gene expression associated with developmental arrest and longevity in Caenorhabditis elegans. Genome Res 200I, II (8): 1346-1352.

26. Wang J, Kim SK: Global analysis of dauer gene expression in Caenorhabditis elegans. Development 2003, I30(8): 162I-1634.

27. McElwee J, Bubb K, Thomas JH: Transcriptional outputs of the Caenorhabditis elegans forkhead protein DAF-16. Aging Cell 2003, 2(2): ||$|-| 2 \mid$.

28. Vanfleteren JR: Oxidative stress and ageing in Caenorhabditis elegans. Biochem J 1993, 292 ( Pt 2):605-608.

29. Jensen LT, Culotta VC: Activation of CuZn superoxide dismutases from Caenorhabditis elegans does not require the copper chaperone CCS. J Biol Chem 2005, 280(50):4I373-4I379.

30. Sulston J, Hodgkin J: Methods. In The nematode Caenorhabditis elegans Edited by: Wood WB. New York, Cold Spring Harbor Laboratory Press; 1988:587-606.

[http://frodo.wi.mit.edu/cgi-bin/primer3/ primer3 www.cgi]

32. MFOLD [http://www.bioinfo.rpi.edu/applications/mfold/]

Publish with Biomed Central and every scientist can read your work free of charge

"BioMed Central will be the most significant development for disseminating the results of biomedical research in our lifetime. "

Sir Paul Nurse, Cancer Research UK

Your research papers will be:

- available free of charge to the entire biomedical community

- peer reviewed and published immediately upon acceptance

- cited in PubMed and archived on PubMed Central

- yours - you keep the copyright

Submit your manuscript here:

http://www.biomedcentral.com/info/publishing_adv.asp
BioMedcentral 